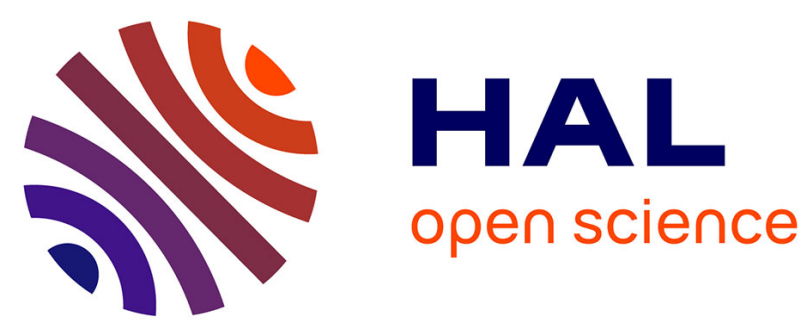

\title{
DNA pyrosequencing evidence for large diversity differences between natural and managed coffee mycorrhizal fungal communities
}

Matthias de Beenhouwer, Diriba Muleta, Bram Peeters, Maarten van Geel, Bart Lievens, Olivier Honnay

\section{To cite this version:}

Matthias de Beenhouwer, Diriba Muleta, Bram Peeters, Maarten van Geel, Bart Lievens, et al.. DNA pyrosequencing evidence for large diversity differences between natural and managed coffee mycorrhizal fungal communities. Agronomy for Sustainable Development, 2015, 35 (1), pp.241-249. 10.1007/s13593-014-0231-8 . hal-01284256

\section{HAL Id: hal-01284256 \\ https://hal.science/hal-01284256}

Submitted on 7 Mar 2016

HAL is a multi-disciplinary open access archive for the deposit and dissemination of scientific research documents, whether they are published or not. The documents may come from teaching and research institutions in France or abroad, or from public or private research centers.
L'archive ouverte pluridisciplinaire HAL, est destinée au dépôt et à la diffusion de documents scientifiques de niveau recherche, publiés ou non, émanant des établissements d'enseignement et de recherche français ou étrangers, des laboratoires publics ou privés. 


\title{
DNA pyrosequencing evidence for large diversity differences between natural and managed coffee mycorrhizal fungal communities
}

\author{
Matthias De Beenhouwer • Diriba Muleta $\cdot$ Bram Peeters • \\ Maarten Van Geel • Bart Lievens • Olivier Honnay
}

Accepted: 14 May 2014 / Published online: 11 June 2014

(C) INRA and Springer-Verlag France 2014

\begin{abstract}
Arabica coffee is a major agricultural commodity worldwide, representing $60 \%$ of the world's coffee production. Arabica coffee is cultivated in more than 36 countries and is a key cash crop for many developing countries. Despite the coffee's huge economic importance, there is very limited knowledge on the association of arbuscular mycorrhizal fungi with coffee roots. Therefore, we assessed the mycorrhizal diversity and community composition in Arabica coffee (Coffea arabica $\mathrm{L}$.), using 454 pyrosequencing, in its Ethiopian center of origin. We studied the five most common coffee management systems in Ethiopia. Using pyrosequencing, we retrieved 10,061 mycorrhizae sequences across 30 samples, generating 36 operational taxonomic units from the four mycorrhizae orders: Glomerales, Diversisporales, Archaeosporales, and Paraglomerales; and eight families. Our results show that mycorrhizal diversity strongly differed between natural forest coffee systems and the other management systems. Furthermore, 13 operational taxonomic units were uniquely found in natural forest coffee. Finally, the mycorrhizal community composition in shade coffee plantations was different from the community composition in the other managed systems and the natural forest coffee systems. This is the first in depth study of mycorrhizal communities in wild coffee in its Ethiopian region of origin. Furthermore, we show for the first time the major differences in
\end{abstract}

M. De Beenhouwer $(\triangle) \cdot$ B. Peeters $\cdot$ M. Van Geel $\cdot$ O. Honnay Plant Conservation and Population Biology, Biology Department, KU Leuven, Kasteelpark Arenberg 31, 3001 Heverlee, Belgium e-mail: matthias.debeenhouwer@bio.kuleuven.be

D. Muleta

Environmental Biotechnology Unit, Institute of Biotechnology, Addis Ababa University, P.O.Box 1176, Addis Ababa, Ethiopia

B. Lievens

Laboratory for Process Microbial Ecology and Bioinspirational Management, Department of Microbial and Molecular Systems (M2S), KU Leuven, Campus De Nayer, Jan De Nayerlaan 5, 2860 Sint-Katelijne-Waver, Belgium mycorrhizal communities in coffee between natural coffee forest and more intensively managed coffee systems. We, therefore, provide evidence of the conservation value of natural coffee forest systems as they harbor a unique mycorrhizal diversity, with possible future applications in low input coffee agriculture.

Keywords Agroforestry $\cdot$ Anthropogenic disturbance · Glomeromycota $\cdot$ High-throughput sequencing · Metagenomics · Southwest Ethiopia

\section{Introduction}

Coffee (Coffea spp.; family Rubiaceae) is the most intensively traded tropical agricultural commodity worldwide. It is currently cultivated in over 50 countries, on an area covering more than 11 million hectares, and it is a key cash crop for many developing countries (Waller et al. 2007). Coffea arabica L. or Arabica coffee is the economically most important species of this genus, representing $60 \%$ of the world's coffee production. The Afromontane rainforest of Southwest Ethiopia is the region of origin and center of genetic diversity of $C$. arabica, where it is geographically isolated from all other Coffea species. Coffee occurs here as a natural understory shrub of Afromontane rainforests (Waller et al. 2007). The yield obtained from coffee growing in these natural forests is low, and increasing human population densities and demand for Arabica coffee on the world market have caused a gradual intensification of the traditional coffee production. This has resulted in coffee agroforestry systems with different degrees of management intensity, ranging from natural forest coffee over semi-plantation coffee to intensively managed shade plantation coffee (Aerts et al. 2011). Other studies have compared these management systems with respect to their effects on above ground biodiversity and ecosystem provisioning (summarized in De Beenhouwer et al. 2013). However, below ground biodiversity 
of these management systems including the mycorrhizal fungi has been studied poorly so far, although their potential importance for plant productivity and ecosystem service delivery is well known (Philippot et al. 2013).

Arbuscular mycorrhizal fungi (phylum Glomeromycota) are obligate symbionts of terrestrial plants occurring in more than $80 \%$ of the plant species (Smith and Read 2008). Arbuscular mycorrhizae receive plant assimilated carbon, while in return they bring a spectrum of benefits to the host plant (Smith and Read 2008). They are known to play an important role in mineral nutrient uptake, especially phosphorus, and to protect the plant from soil borne pathogens and drought (Smith and Read 2008). For these reasons, mycorrhizae may have important applications in low input and organic agriculture where the mycorrhizal species diversity and abundance are generally higher than in more intensively managed and conventional agricultural systems (Verbruggen et al. 2010). So far, our knowledge of the mycorrhizal diversity and abundance in different crop species, and how mycorrhizal communities differ between management systems, remains limited. This is certainly the case for crops cultivated in Africa, although it is in the typical African low input agricultural systems that mycorrhizae may be especially beneficial for crop production.

It is already known for more than hundred years that arbuscular mycorrhizae colonize coffee roots (Janse 1897). Vaast et al. (1996) demonstrated with in vitro propagated coffee seedlings in a pot experiment the high mycorrhizal dependency of $C$. arabica. Furthermore, in low input agricultural systems, roots from $C$. arabica seedlings have been shown to be highly colonized by mycorrhizae (Lebrón et al. 2012). Up to now, however, all knowledge regarding mycorrhizal diversity in C. arabica is based on the morphological analysis of the spores, and almost all of this research has been carried out in Latin American coffee plantations (Andrade et al. 2009). These coffee plantations were found to be dominated by the genera Glomus and Acaulospora (reviewed in Andrade et al. 2009). Recently, Arias et al. (2012) microscopically identified 33 morphospecies of arbuscular mycorrhizae belonging to six different genera (Acaulospora, Ambispora, Entrophospora, Gigaspora, Glomus, and Scuttelospora) in the soils of Mexican coffee plantations. These authors could not find significant differences in spore diversity between coffee production systems of different management intensity.

Apart from studies performed by Muleta and coworkers (Muleta et al. 2008), the mycorrhizal communities of Arabica coffee in its Ethiopian center of origin have remained unstudied so far. These studies, based on the morphological identification of spores, revealed a relatively high diversity (covering five genera: Acaulospora, Ambispora, Entrophospora, Glomus, and Scuttelospora) in the soil of coffee plantations, although no difference in species richness was found between unshaded and shaded coffee plantations (Muleta et al. 2008). However, spores in the soil do not necessarily represent mycorrhizae in the host plant, and mycorrhizal richness can be considerably underestimated when only morphological criteria are taken into account (Sanders 2004). Therefore, molecular approaches have increasingly become the standard for studying mycorrhizal communities (Krüger et al. 2012). Next generation sequencing technologies such as 454 pyrosequencing have enabled highly efficient characterization of diverse microbial communities (Lienhard et al. 2013), including mycorrhizal communities (Lumini et al. 2010). One of the most important benefits of this technology is the ability to process many samples simultaneously at a low cost per sequence. Additionally, the depth of sequencing provided allows not only for the detection of the dominant community members, but also for the rare species.

The objective of this study was to provide the first in depth assessment of the mycorrhizal diversity and community composition in C. arabica in its Ethiopian center of origin, using 454 pyrosequencing. Secondly, we aimed to compare the mycorrhizal diversity and composition among the five main Arabica coffee management systems present in Ethiopia.

\section{Materials and methods}

\subsection{Study sites and sampling}

This study was conducted in the Jimma zone of the Oromo region in Southwest Ethiopia, where C. arabica grows naturally as a forest understory shrub (Fig. 1). This region, with an altitude ranging between 1,500 and 2,500 $\mathrm{m}$ above sea level, is characterized by a humid and warm subtropical climate with a yearly rainfall between 1,800 and 2,300 $\mathrm{mm}$, and the main rainy season from July to September. Differences in temperature throughout the year are small with a mean annual temperature between 15 and $22{ }^{\circ} \mathrm{C}$.

We studied the five main Ethiopian coffee management systems representing different levels of management intensification and anthropogenic disturbance (Table 1; Fig. 1): The forest coffee system represents coffee growing in natural forests without anthropogenic disturbance. In the semi-forest coffee system, there is limited anthropogenic disturbance of the soil, through local replanting of coffee seedlings and undergrowth slashing before harvest. The canopy is more open through selective thinning of emergent tree species (Aerts et al. 2011). In the semi-plantation coffee system, there is a high anthropogenic disturbance resulting in an open, species poor canopy layer. Coffee density is high because of the planting of local cultivars between the wild coffee individuals. Local cultivars did not result from rigorous breeding, however, and still represent a very high genetic diversity (Aerts et al. 2012). Furthermore, organic fertilizer is locally applied. The home garden coffee system represents coffee from gardens near homesteads. Coffee plants are local cultivars grown under the shade of fruit 

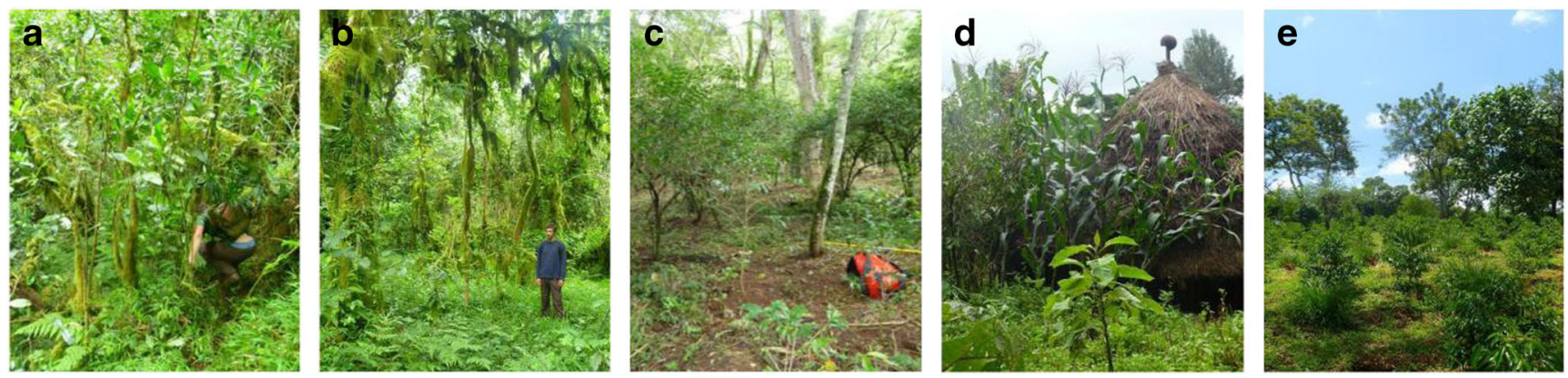

Fig. 1 Coffee (Coffea arabica L.) shrub layer sampled across the different management systems, indicating different management practices a forest coffee system, $\mathbf{b}$ semi-forest coffee system, $\mathbf{c}$ semi-plantation coffee system, $\mathbf{d}$ home garden coffee system, and $\mathbf{e}$ plantation coffee system

trees. Coffee grows in between other crops, and manure is sometimes applied as organic fertilizer. The plantation coffee system represented coffee from shade plantations with only very few canopy trees, regular herbicide (Glyphosate) and fertilizer application (both nitrogen and phosphorus; Table 1) and the use of local cultivars.

In August and September 2012, root samples were collected from adult coffee individuals (Height; $>1.5 \mathrm{~m}$ and diameter at breast height; $>3 \mathrm{~cm}$ ) across the five different management systems (Table 1). Eight plants from the forest coffee system were sampled in the Belete-Gera forest area $\left(7^{\circ} 48^{\prime} \mathrm{N}, 36^{\circ} 20^{\prime}\right.$ $\mathrm{E}$ ), one of the last remaining moist evergreen Afromontane rainforests in the Jimma zone. In the same forest area, eight coffee plants were sampled in the semi-forest coffee system $\left(7^{\circ}\right.$ $47^{\prime} \mathrm{N}, 36^{\circ} 20^{\prime} \mathrm{E}$ ). Twelve and eight samples from the semiplantation coffee system $7^{\circ} 44^{\prime} \mathrm{N}, 36^{\circ} 45^{\prime} \mathrm{E}$ and home garden coffee systems $7^{\circ} 44^{\prime} \mathrm{N}, 36^{\circ} 48^{\prime} \mathrm{E}$, respectively, were collected in the Garuke locality, close to Jimma town, in a landscape consisting of isolated forest fragments that are specifically managed for coffee production. Finally, roots from eight coffee individuals in three government coffee plantations (Gommaa 1, Gommaa 2, and Limu Kossa) were included, representing the plantation coffee system $\left(7^{\circ} 56^{\prime} \mathrm{N}, 36^{\circ} 37^{\prime} \mathrm{E}\right)$. All samples were taken from roots in the top soil $(0-30 \mathrm{~cm})$ on three locations around the coffee plant (Mummey and Rillig 2008). Care was taken to collect only fine young roots, as this is where most of the mycorrhizal colonization occurs (Smith and Read 2008). Roots were cleansed, placed in paper bags, transported to the laboratory, dried with silica gel beads, and stored at room temperature until further processing. For each management system, 20 soil samples $(0-30 \mathrm{~cm}$ below the litter layer) were taken with a soil auger in the proximity of 20 randomly selected coffee plants. Canopy cover was also measured with a spherical densitometer at these selected points.

\subsection{Soil physicochemical analysis}

Soil analyses were conducted in the laboratory on fresh soil samples (stored in a refrigerator at $5{ }^{\circ} \mathrm{C}$ for maximum of 1 month prior to analysis). We determined soil $\mathrm{pH}$ with a $\mathrm{pH}$ probe in a 1:25 soi/deionized water mixture. Ammonium and nitrate were determined as a measure of soil inorganic nitrogen availability by shaking $10 \mathrm{mg}$ dry weight equivalent of soil in $100 \mathrm{ml}$ of $1 \mathrm{M}$ kaliumchloride solution for $1 \mathrm{~h}$. Extracts were analyzed colorimetrically using a segmented flow auto analyzer (Skalar, Breda, and the Netherlands). As a measure of soil inorganic phosphor availability, Olson phosphate values were determined by shaking $2 \mathrm{~g}$ dry weight equivalent of soil for $30 \mathrm{~min}$ with $0.5 \mathrm{M}$ sodium bicarbonate at $\mathrm{pH} 8.5$ and subsequent colorimetric analysis of the extracts using the molybdenum blue method (Robertson et al. 1999).

\subsection{Assessment of mycorrhizal communities using 454 pyrosequencing}

Roots were surface sterilized and microscopically assessed for mycorrhizal colonization. Subsequently, from the pooled root samples, DNA was extracted from $0.5 \mathrm{~g}$ mycorrhizal root tip fragments using the UltraClean Plant DNA Isolation Kit as described by the manufacturer (Mo Bio Laboratories Inc., Solana Beach, CA, USA). Afterwards, an amplicon library was created using barcode-tagged fusion primers of the primer pair NS31-AML2 targeting the small subunit ribosomal RNA and generating amplicons of c. 550 bp (Öpik et al. 2013). Primers were designed according to the guidelines for 454 GS-FLX Titanium Lib-L sequencing, containing the Roche 454 pyrosequencing adapters and a 10 bp sample-specific molecular identifier barcode, allowing identification of the amplicons generated from each PCR reaction. PCR amplification was performed using a Biorad T100 thermal cycler (Biorad, Hercules, CA, USA) in a reaction volume of $20 \mu \mathrm{l}$, containing $0.15 \mathrm{mM}$ of each dNTP, $0.5 \mu \mathrm{M}$ of each primer, $1 \times$ Titanium Taq PCR buffer, 1 U Titanium Taq DNA polymerase (Clontech Laboratories, Palo Alto, CA, USA), and $1 \mu$ l of 10× diluted genomic DNA. The PCR conditions used were as follows: initial denaturation of $2 \mathrm{~min}$ at $94{ }^{\circ} \mathrm{C}$, followed by 35 cycles of $45 \mathrm{~s}$ at $94{ }^{\circ} \mathrm{C}, 45 \mathrm{~s}$ at $58^{\circ} \mathrm{C}$, and $45 \mathrm{~s}$ at $72{ }^{\circ} \mathrm{C}$, and a final extension step of $10 \mathrm{~min}$ at $72^{\circ} \mathrm{C}$. Samples from two PCR runs per DNA extract were pooled and after separating the PCR products by agarose gel electrophoresis, target 


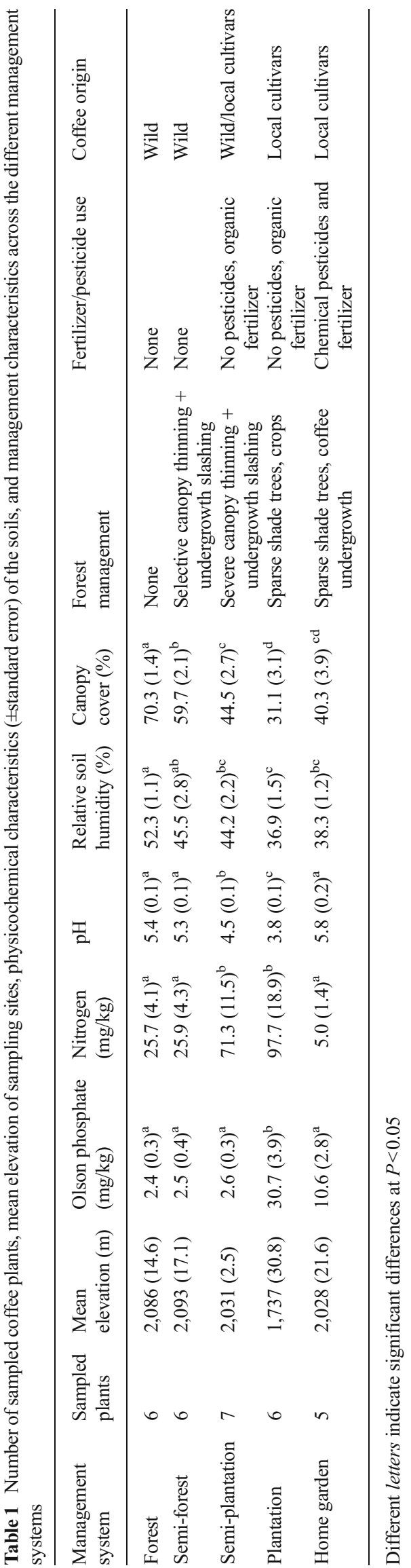

amplicons were cut from the gel and purified using the Qiaquick gel extraction kit (Qiagen, Hamburg, Germany). Purified dsDNA amplicons were quantified using the QuantiT PicoGreen ${ }^{\circledR}$ dsDNA Assay Kit and the Qubit ${ }^{\mathrm{TM}}$ fluorometer (both from Invitrogen, Ghent, Belgium), and pooled in equimolar amounts $\left(9.5 \times 10^{6}\right.$ molecules $\mu 1$ per sample). The quality of the resulting amplicon library was assessed using an Agilent Bioanalyzer 2100 and high sensitivity DNA chip (Agilent Technologies, Waldbronn, Germany). Pyrosequencing was performed on the amplicon library using the Roche GS FLX instrument (one out of eight lanes of a 454 picotiter plate) and Titanium chemistry according to the manufacturer's instructions (Roche Applied Science, Mannheim, Germany).

\subsection{Sequence processing}

Sequences obtained from the 454 pyrosequencing run were analysed using MOTHUR v. 1.31.2 (Schloss et al. 2009) according to Bik et al. (2012). Pairwise distances were calculated using default settings in MOTHUR to cluster the sequences into operational taxonomic units at $97 \%$ sequence similarity, which is commonly used to define operational taxonomic units in fungi (Buée et al. 2009). In order to assign the operational taxonomic units, a taxonomic identity, representative sequences from each operational taxonomic unit (as determined by MOTHUR) were subjected to a BLAST search against GenBank (Altschul et al. 1990). Identifications were considered reliable when a BLAST score $>250$ and an expected value (E-value) $<10^{-50}$ was obtained (Lumini et al. 2010).

A maximum likelihood phylogenetic tree was constructed based on the representative sequences for each operational taxonomic unit and reference sequences from the Krüger database (Krüger et al. 2012) to assess the phylogenetic relationships between the different operational taxonomic units (data not shown). Operational taxonomic units that could not be assigned to the phylum Glomeromycota in this manner were removed from our dataset. Additionally, operational taxonomic units representing 'global singletons', i.e., represented by only a single sequence over the entire dataset, were removed from further analysis in order to minimize the risk of having sequences that resulted from sequencing errors. Removing singletons has previously been shown to improve the accuracy of diversity estimates (Tedersoo et al. 2010). Subsequently, to accurately identify the remaining mycorrhizae, the representative sequences for each remaining operational taxonomic unit were queried against the MaarjAM database (Öpik et al. 2010) by BLAST search on a local computer. The MaarjAM database summarizes available Glomeromycota sequence data, facilitating identification of reference sequences in this group (Öpik et al. 2010). Representative sequences for each operational taxonomic unit determined in this study are accessible at GenBank through accession numbers KF911355- KF911389. 


\subsection{Data analysis}

Results from the BLAST analysis against GenBank were used to determine the number of sequences belonging to the Glomeromycota. Subsequently, the relative abundances of each Glomeromycota order and family were calculated using the results of the BLAST search against the MaarjAM database. In order to assess the overall richness of mycorrhizae in the different management systems, rarefaction curves were generated using ESTIMATE S V.8.2 (Colwell et al. 2012) with 100 randomizations and sampling without replacement. Furthermore, alpha diversity, Shannon diversity, and the nonparametric abundance-based coverage estimator and incidence coverage-based estimator were calculated with ESTIMATE S.

Pairwise Jaccard similarity indices were calculated with MOTHUR to estimate community overlap between management systems (Schloss et al. 2009). Additionally, nonmetric multidimensional scaling was used to visualize possible differences in the mycorrhizal communities. The ordination was run on the presence-absence data using the Sørensen distance measure, with six starting dimensions, 40 iterations, and an instability criterion of $10^{-5}$ (McCune and Mefford 2006).

Distance measures from the ordination and diversity indices were compared between the different management systems using linear mixed models conducted in SPSS 22.0 for Windows (SPSS Inc., Chicago, IL). Because sometimes samples were taken within the same forest or plantation, we included 'Study site' in the models as a random factor to account for pseudoreplication. To account for differences in the number of obtained sequences per sample, 'Sequencing depth' was used as a covariate in the linear mixed model when comparing diversity indices between management systems. Still, some samples yielded very few sequences (less than ten sequences), which probably resulted from too few target DNA in these samples, and were therefore omitted from further analyses to avoid sequencing bias. Finally, differences among management systems in canopy closure and physicochemical characteristics were analyzed by analysis of variance (followed by Tukey's test for pairwise comparisons).

\section{Results and discussion}

3.1 Differences in soil and canopy between coffee management systems

The environmental variables around the coffee plants differed significantly between management systems (Table 1). The canopy cover was significantly different between all management systems, except between the home garden and plantation coffee system. Total nitrogen (ammonium + nitrate) differed significantly between the (semi-)plantation coffee system and the other management systems. Furthermore, the plantation coffee system had a significantly higher Olson phosphate level and lower $\mathrm{pH}$ as compared to the other management systems (Table 1).

\subsection{Mycorrhizal colonization of Coffea arabica}

The amplicon library generated 10,061 high quality mycorrhizal sequences over all samples. After the removal of the global singletons, 36 operational taxonomic units were retained, representing between 2 and 5,016 sequences per operational taxonomic unit. Out of the 36 operational taxonomic units, 15 were classified in the order of Diversisporales, 10 as Glomerales, 7 as Archaeosporales, and 4 as Paraglomerales. Glomerales were found as the most abundant order, representing $51.2 \%$ of all obtained sequences, followed by Diversisporales (24.6\%), Paraglomerales (18.9\%), and Archaeosporales (5.4\%). Most sequences were obtained for forest coffee samples (median 349.5 sequences per sample), while less sequences were obtained for samples from the semi-forest (192.5), semi-plantation (109), home garden (49.5), and plantation coffee system (33).

The arbuscular mycorrhizae found in our study represented eight families over the four orders. Acaulosporaceae, Gigasporaceae, and Diversisporaceae represented families of the Diversisporales. The Glomerales were represented by Glomeraceae and Claroideoglomeraceae and the Paraglomeraceae family represented the Paraglomerales. Ambisporaceae and Archaeosporaceae were the two families found in the order of the Archaeosporales. Rarefaction curves, assessing accumulated mycorrhizal richness at the level of management systems, generally tended to approach saturation (Fig. 2a) while the observed richness approached the expected richness as estimated by the abundance coverage estimator (except for the home garden coffee system) and the incidence coverage-based estimator (except for the forest coffee system) (Table 2). This indicates that the sequencing depth in this study was able to cover the bulk of mycorrhizal diversity in the sampling area.

Acaulosporaceae (9 operational taxonomic units), Glomeraceae (7), and Archaeosporaceae (5) were the most abundant families. The most common operational taxonomic unit, present in $97 \%$ of the samples, represented a Glomus member and accounted for almost $50 \%$ of the obtained sequences. This finding is in line with Muleta et al. (2008) who also reported Glomus as the most dominant genus in coffee soils in Ethiopia. Furthermore, studies from other coffee production regions worldwide revealed a similar dominance of this genus (Andrade et al. 2009). Moreover, Glomus spp. have been found dominant in diverse ecosystems regardless of the degree of disturbance or land use system (Öpik et al. 2013), suggesting that this genus is resistant to anthropogenic disturbance. 


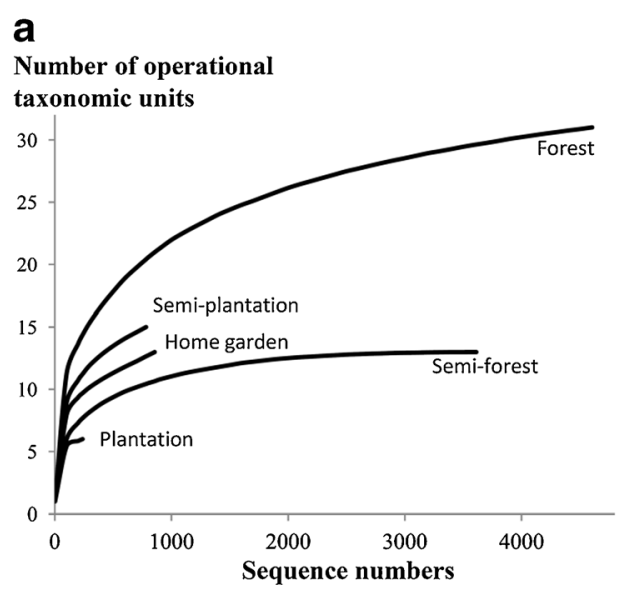

Fig. 2 a Rarefaction curves generated for each coffee management system, illustrating accumulated number of operational taxonomic units (based on a DNA dissimilarity cutoff value of $3 \%$ ) of arbuscular mycorrhizal fungi, found in Coffea arabica roots. The rarefaction curves indicate that overall mycorrhizal richness is highest in the forest coffee system and lowest in the plantation coffee system, also at equal sequence

\subsection{Differences of mycorrhizal diversity in coffee}

between management systems

The number of families detected generally differed between management systems, ranging from eight families in forest coffee system to four in the plantation coffee system (Fig. 3). Ambisporaceae, for example, were exclusively found in the forest coffee system, represented here by two operational taxonomic units. Additionally, families such as Claroideoglomeraceae, Gigasporaceae, and Diversisporaceae, occurring in most of the management systems, were all absent from the plantation coffee system (Fig. 3). Only the four most abundant families (Glomeraceae, Acaulosporaceae, Paraglomeraceae, and Archaeosporaceae) were found in the plantation coffee system.

The overall mycorrhizal richness differed between management systems, with most mycorrhizae obtained in b

Mean mycorrhizal richness

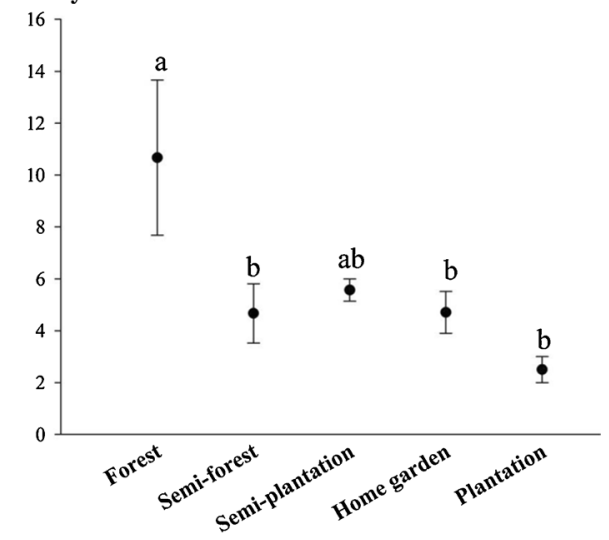

numbers. b Mean mycorrhizal richness $( \pm \mathrm{SE})$ calculated from linear mixed models per management system. The highest mycorrhizal richness was found on coffee roots in forest as compared to coffee in other managements systems. Different letters indicate significant differences at $P<0.05$, corrected for unequal sequence depth, between these management systems

the forest coffee system ( 31 operational taxonomic units) and least for the plantation coffee system (6; Table 2). The linear mixed model revealed significant differences in richness among the different management systems $(F=$ 3.51, $P=0.022$ ). Least significant difference tests revealed significantly higher richness in the forest coffee system as compared to the semi-forest, home gardens, and plantation coffee system $(P=0.002,0.03$, and 0.014 , respectively; Fig. 2b). Furthermore, the Shannon diversity index differed similarly between management systems $(F=$ 9.06, $P<0.01)$. Least significant difference tests revealed significant higher Shannon diversity in the forest coffee system as compared to the semi-forest, home garden, and plantation coffee system $(P=0.016,0.02$, and 0.01 , respectively; Table 2), and significant higher Shannon diversity in the semi-forest and semi-plantation coffee system as compared to the plantation coffee system $(P=0.01$

Table 2 Arbuscular mycorrhizal fungi diversity indices ( \pm standard deviations) across different coffee management systems. Diversity indices were the highest in forest coffee and the lowest in plantation coffee

\begin{tabular}{llllll}
\hline & Forest & Semi-forest & Semi-plantation & Plantation & Home garden \\
\hline Number of OTUs & 31 & 13 & 15 & 6 & 13 \\
Number of families & 8 & 7 & 6 & 4 & 6 \\
Number of unique OTUs & 13 & 2 & 1 & 0 & 1 \\
Mean alpha $( \pm \mathrm{SD})$ & $2.1( \pm 0.9)^{\mathrm{a}}$ & $1.22( \pm 0.26)^{\mathrm{bc}}$ & $1.55( \pm 0.7)^{\mathrm{ab}}$ & $0.77( \pm 0.43)^{\mathrm{c}}$ & $1.11( \pm 0.32)^{\mathrm{bc}}$ \\
Shannon diversity $( \pm \mathrm{SD})$ & $1.45( \pm 0.21)^{\mathrm{a}}$ & $0.98( \pm 0.15)^{\mathrm{b}}$ & $1.1( \pm 0.37)^{\mathrm{ab}}$ & $0.45( \pm 0.36)^{\mathrm{c}}$ & $0.75( \pm 0.28)^{\mathrm{bc}}$ \\
ACE $( \pm \mathrm{SD})$ & $36.69( \pm 7.97)^{\mathrm{a}}$ & $13( \pm 1.45)^{\mathrm{ab}}$ & $19.61( \pm 2.37)^{\mathrm{ab}}$ & $6( \pm 0.71)^{\mathrm{b}}$ & $34.67( \pm 7.11)^{\mathrm{ab}}$ \\
ICE $( \pm \mathrm{SD})$ & $64.29( \pm 19.83)^{\mathrm{a}}$ & $28.8( \pm 5.66)^{\mathrm{ab}}$ & $25.06( \pm 5.67)^{\mathrm{ab}}$ & $6.48( \pm 0.83)^{\mathrm{b}}$ & $24.5( \pm 4.6)^{\mathrm{ab}}$ \\
\hline
\end{tabular}

Different letters between management systems indicate significant differences at $P<0.05$

OTUS operational taxonomic units (grouped based on a DNA dissimilarity cutoff value of $3 \%$ ), $A C E$ abundance-based coverage estimator, $I C E$ incidence-based coverage estimator 


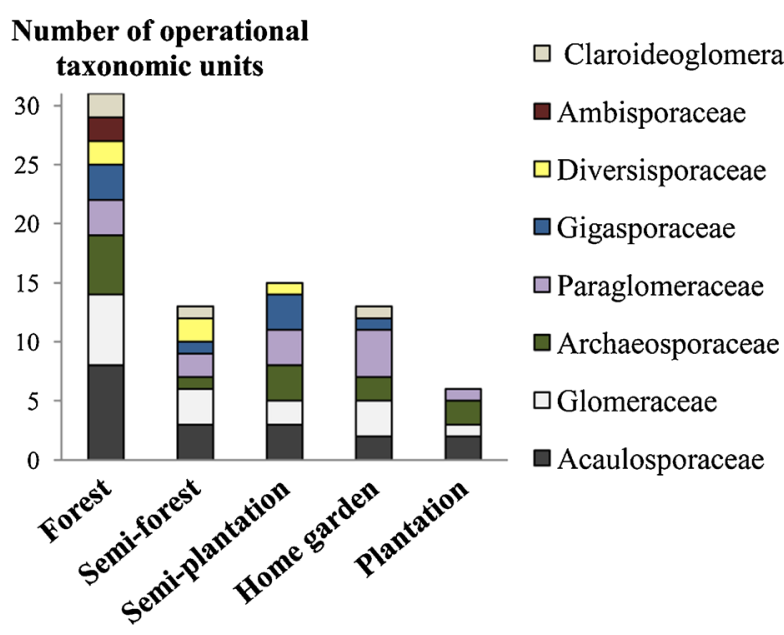

Fig. 3 Distribution of the families of arbuscular mycorrhizal fungi present in Coffea arabica roots among the different coffee management systems. The $y$-axis indicates the number of operational taxonomic units (grouped based on a DNA dissimilarity cutoff value of $3 \%$ ) in the different families. The families belong to the orders of Archaeosporales (Archaeosporaceae and Claroideoglomeraceae), Diversisporales (Diversisporaceae, Acaulosporaceae, and Gigasporaceae), Glomerales (Glomeraceae and Ambisporaceae), and Paraglomerales (Paraglomeraceae). Forests harbored a higher richness of mycorrhizal fungi as compared to other management systems, both at family level and at operational taxonomic unit level

and 0.014 , respectively; Table 2). The forest coffee plants were highly colonized by rare mycorrhizae, with 13 operational taxonomic units uniquely found in the forest coffee system, compared to 2 in semi-forest, 1 in semiplantation and home garden, and none in the plantation coffee system. These results show that $C$. arabica from wild origin in natural forest is highly colonized by mycorrhizae as compared to C. arabica from other management systems. The significant differences in mycorrhizal diversity that are observed between the forest coffee system and the semi-forest coffee system may be explained by modifications in the forest canopy structure and soil disturbance through undergrowth slashing and the planting of additional coffee seedlings in the semi-forest coffee system. Furthermore, undergrowth slashing and canopy thinning may have resulted in changes of the soil microclimate, which is known to affect the soil microbial communities (Castro et al. 2010). Finally, canopy thinning and understory slashing may increase mineralization rates, which may have resulted in a decreased mycorrhizal dependency of coffee plants (Johnson et al. 2013). Our result provides a strong evidence of the conservation value of the forest coffee system as they harbor a unique mycorrhizal diversity with possible future applications in low input coffee agriculture. However, further research on the identification of the specific environmental variables that mediate the variation in coffee mycorrhizal communities across different management systems is required.
3.4 Differences of mycorrhizal community composition in coffee between management systems

Out of the 36 mycorrhizal species found in our study, three were shared by all management systems. These represented members of three different orders, including Glomerales (Glomus), Diversisporales (Acaulospora), and Archaeosporales (Archaeospora), and accounted for $71.1 \%$ of all obtained sequences. Pairwise Jaccard similarity indices demonstrated that the highest dissimilarity were found between mycorrhizal communities of the forest and the plantation coffee system, while communities of the home garden and plantation coffee system showed the highest similarity (data not shown).

For the nonmetric multidimensional scaling, the greatest reduction in stress was achieved with a three-dimensional solution (cumulative $R^{2}=0.81$ ). In the ordination, sample distribution followed the management systems along the second axis and the third axis, explaining 31.7 and $31.9 \%$ of the variation, respectively (Fig. 4). Management systems were significantly partitioned along the second axis $(F=3.65, P=$ 0.018 ), with a significant difference between the forest coffee system on the one hand and the semi-forest, semi-plantation, home garden, and plantation coffee system on the other hand ( $P=0.026,0.044,0.017$, and 0.001 , respectively). Forest coffee plants thus have a significantly different mycorrhizal community as compared to coffee plants from the other management systems, further stressing the unique position of wild, naturally growing coffee in mycorrhizal symbiosis. Communities were further separated along the third axis $(F=5.52, P=$ 0.003 ), with a significant difference between the plantation coffee system on the one hand and the forest, semi-forest,

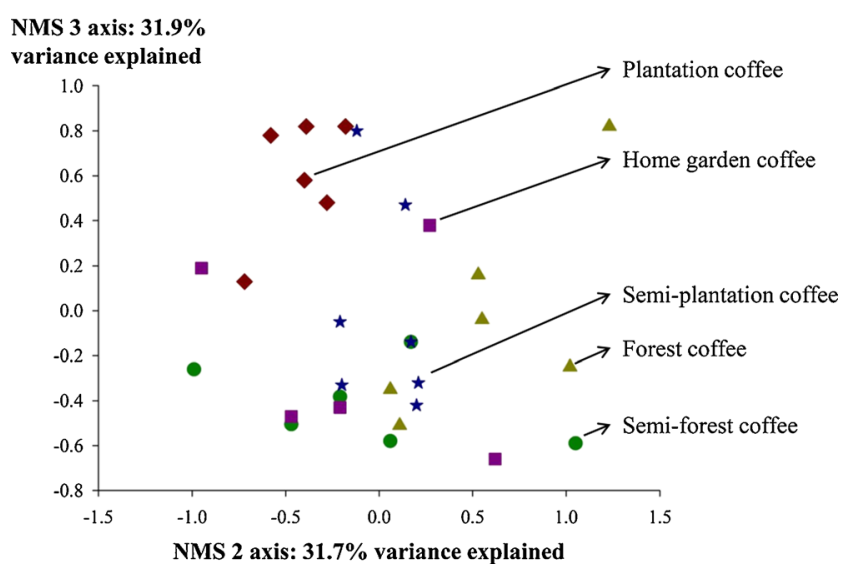

Fig. 4 Nonmetric multidimensional scaling (NMS) ordination plot of the arbuscular mycorrhizal fungi community composition in Coffea arabica roots among different coffee management systems. The closer samples occur within the plot, the more their mycorrhizal community composition resembles. Significantly different communities were observed between forest coffee and coffee from other management systems along the NMS2 axis and between plantation coffee and coffee from other management systems along the NMS3 axis, indicating shifting communities of mycorrhizae when coffee is differently cultivated 
semi-plantation, and home garden coffee system on the other hand ( $P=0.01,0.001,0.02$, and 0.003 , respectively). Plantation coffee plants thus have a significantly different community composition as compared to coffee plants from the other management systems. Together with the low amount of mycorrhizae (six operational taxonomic units) found in the plantation coffee system, this community shift suggests that plantations may represent the least hospitable environment for mycorrhizal symbiosis in coffee agroforestry. In contrast to the other management systems, chemical fertilizers and pesticides are abundantly used in the plantation coffee system, which are known to change the soil characteristics and plantmicroorganism interactions thoroughly (Tilman et al. 2002; Verbruggen et al. 2010). Phosphorus application in specific, which was significantly higher in the plantation coffee system as compared to other management systems, has been found to significantly change the mycorrhizal symbiosis in coffee (Vaast et al. 1996).

\section{Conclusions}

Our results indicate a strong difference in mycorrhizal diversity and community composition in roots of $C$. arabica when the forest coffee system is compared with other coffee management systems. Therefore, our study stresses the unique position of natural, wild coffee for its associated mycorrhizal symbiosis. Conserving populations of natural wild Arabica coffee through better forest protection therefore not only ensures in situ conservation of coffee genetic resources, but also protects its high mycorrhizal diversity with possible future applications in low input agriculture. Although the aim of our work was not to quantify the effects of mycorrhizal diversity on coffee productivity, one may expect that loss of mycorrhizal diversity, and especially the loss of entire families, can have important implications for plant productivity (Maherali and Klironomos 2007; Jansa et al. 2008). Therefore, further research on the identification of the specific environmental variables that mediate the variation in coffee mycorrhizal communities across management systems, and on the link between mycorrhizal diversity and coffee plant productivity is required.

Acknowledgments This research was carried out within the framework of the Institutional University Collaboration partnership between Jimma University and universities in Flanders (JU-IUC), which is funded by the University Development Cooperation of the Flemish Interuniversity Council (VLIR-UOS). M.D.B. held a VLADOC grant (VLIR-UOS). We gratefully acknowledge the farmers who allowed us to work in their coffee forest, the government for cooperation in the plantations and Sabit, Tijani, Amino, and Aba Sharo for their assistance during data collection. Further, we appreciate the advice of Michael Waud and Pieter Busschaert on how to perform and analyze the 454 pyrosequencing run. We thank the three anonymous reviewers for detailed comments that greatly improved the manuscript.

\section{References}

Aerts R, Hundera K, Berecha G, Gijbels P, Baeten M, Van Mechelen M, Hermy M, Muys B, Honnay O (2011) Semi-forest coffee cultivation and the conservation of Ethiopian Afromontane rainforest fragments. Forest Ecol Manag 261:1034-1041. doi:10.1016/j.foreco. 2010.12.025

Aerts R, Berecha G, Gijbels P, Hundera K, Van Glabeke S, Vandepitte K, Muys B, Roldan-Ruiz I, Honnay O (2012) Genetic variation and risks of introgression in the wild Coffea arabica gene pool in southwestern Ethiopian montane rainforests. Evol Appl 6:243252. doi:10.1111/j.1752-4571.2012.00285.x

Altschul SF, Gish W, Miller W, Myers EW, Lipman DJ (1990) Basic local alignment search tool. J Mol Biol 215:403-410. doi:10.1016/ S0022-2836(05)80360-2

Andrade SAL, Mazzafera P, Schiavinato MA, Silveira APD (2009) Arbuscular mycorrhizal association in coffee. J Agric Sci 147: 105-115. doi:10.1017/S0021859608008344

Arias RM, Heredia-Abarca G, Sosa VJ, Fuentes-Ramirez LE (2012) Diversity and abundance of arbuscular mycorrhizal fungi spores under different coffee production systems and in a tropical montane cloud forest patch in Veracruz, Mexico. Agrofor Syst 85:179-193. doi:10.1007/s10457-011-9414-3

Bik HM, Porazinska DL, Creer S, Caporaso G, Knight R, Thomas WK (2012) Sequencing our way towards understanding global eukaryotic biodiversity. Trends Ecol Evol 27:233-243. doi:10.1016/j.tree. 2011.11.010

Buée M, Reich M, Murat C, Morin E, Nilsson RH, Uroz S, Martin F (2009) 454 Pyrosequencing analyses of forest soils reveal an unexpectedly high fungal diversity. New Phytol 184:449-456. doi:10. 1111/j.1469-8137.2009.03003.x

Castro HF, Classen AT, Austin EE, Norby RJ, Schadt CW (2010) Soil microbial community responses to multiple experimental climate change drivers. Appl Environ Microbiol 76:999-1007. doi:10.1128/ AEM.02874-09

Colwell RK, Chao A, Gotelli NJ, Lin S, Mao CX, Chazdon RL, Longino JT (2012) Models and estimators linking individual-based and sample-based rarefaction, extrapolation, and comparison of assemblages. J Plant Ecol 5:3-21. doi:10.1093/jpe/rtr044

De Beenhouwer M, Aerts R, Honnay O (2013) A global meta-analysis of the biodiversity and ecosystem service benefits of coffee and cacao agroforestry. Agric Ecosyst Environ 175. doi:10.1016/j.agee.2013. 05.003

Jansa J, Smith FA, Smith SE (2008) Are there benefits of simultaneous root colonization by different arbuscular mycorrhizal fungi? New Phytol 177:779-789. doi:10.1111/j.1469-8137.2007.02294.x

Janse JM (1897) Les endophytes radicaux de quelques plantes javanaises. Ann Jard Bot Buitenzorg 14:53-2010

Johnson NC, Angelard C, Sanders IR, Kiers ET (2013) Predicting community and ecosystem outcomes of mycorrhizal responses to global change. Ecol Lett 16:140-153. doi:10.1111/ele.12085

Krüger M, Krüger C, Walker C, Stockinger H, Schüßler A (2012) Phylogenetic reference data for systematics and phylotaxonomy of arbuscular mycorrhizal fungi from phylum to species level. New Phytol 193:970-984. doi:10.1111/j.1469-8137.2011.03962.x

Lebrón L, Lodge DJ, Bayman P (2012) Differences in Arbuscular mycorrhizal fungi among three coffee cultivars in Puerto Rico. ISRN Agron. doi:10.5402/2012/148042

Lienhard P, Terrat S, Prévost-Bourré NC et al (2013) Pyrosequencing evidences the impact of cropping on soil bacterial and fungal diversity in Laos tropical grassland. Agron Sustain Dev. doi:10.1007/ s13593-013-0162-9

Lumini E, Orgiazzi A, Borriello R, Bonfante P, Bianciotto V (2010) Disclosing arbuscular mycorrhizal fungal biodiversity in soil through a land-use gradient using a pyrosequencing approach. 
Environ Microbiol 12:2165-2179. doi:10.1111/j.1462-2920.2009. 02099.x

Maherali H, Klironomos JN (2007) Influence of phylogeny on fungal community assembly and ecosystem functioning. Science 316 : 1746-1748. doi:10.1126/science.1143082

McCune B, Mefford MJ (2006) PC-ORD for Windows. In: Multivariate analysis of ecological data. Version 5. 31. MjM Software, Gleneden Beach, OR

Muleta D, Assefa F, Nemomissa S, Granhall U (2008) Distribution of arbuscular mycorrhizal fungi spores in soils of smallholder agroforestry and monocultural coffee systems in southwestern Ethiopia. Biol Fertil Soils 44:653-659. doi:10.1007/s00374-007-0261-3

Mummey DL, Rillig MC (2008) Spatial characterization of arbuscular mycorrhizal fungal molecular diversity at the submetre scale in a temperate grassland. FEMS Microbiol Ecol 64:260-270. doi:10. 1111/j.1574-6941.2008.00475.x

Öpik M, Vanatoa A, Vanatoa E, Moora M, Davison J, Kalwij JM, Reier Ü, Zobel M (2010) The online database MaarjAM reveals global and ecosystemic distribution patterns in arbuscular mycorrhizal fungi (Glomeromycota). New Phytol 188:223-241. doi:10.1111/j. 1469-8137.2010.03334.x

Öpik M, Zobel M, Cantero JJ et al (2013) Global sampling of plant roots expands the described molecular diversity of arbuscular mycorrhizal fungi. Mycorrhiza 23:411-430. doi:10.1007/s00572-013-0482-2

Philippot L, Spor A, Hénault C, Bru D, Bizouard F, Jones CM, Sarr A, Maron P-A (2013) Loss in microbial diversity affects nitrogen cycling in soil. ISME J 7:1609-1619. doi:10.1038/ismej.2013.34

Robertson GP, Coleman DC, Bledsoe CS, Sollins P (1999) Standard methods in long term ecological research. Oxford University Press, New York
Sanders IR (2004) Plant and arbuscular mycorrhizal fungal diversity: are we looking at the relevant levels of diversity and are we using the right techniques? New Phytol 164:415-418. doi:10.1111/j.14698137.2004.01208.x

Schloss PD, Westcott SL, Ryabin T et al (2009) Introducing mothur: Open-source, platform-independent, community-supported software for describing and comparing microbial communities. Appl Environ Microbiol 75:7537-7541. doi:10.1128/AEM.01541-09

Smith SE, Read DJ (2008) Mycorrhizal symbiosis. Academic, London. doi:10.2136/sssaj2008.0015br

Tedersoo L, Nilsson RH, Abarenkov K et al (2010) 454 Pyrosequencing and Sanger sequencing of tropical mycorrhizal fungi provide similar results but reveal substantial methodological biases. New Phytol 188:291-301. doi:10.1111/j.1469-8137.2010.03373.x

Tilman D, Cassman KG, Matson PA, Naylor R, Polasky S (2002) Agricultural sustainability and intensive production practices. Nature 418:671-677. doi:10.1038/nature01014

Vaast P, Zasoski RJ, Bledsoe CS (1996) Effects of vesiculararbuscular mycorrhizal inoculation at different soil $\mathrm{P}$ availabilities on growth and nutrient uptake of in vitro propagated coffee (Coffea arabica L.) plants. Mycorrhiza 6:493-497. doi:10.1007/s005720050153

Verbruggen E, Röling WFM, Gamper HA, Kowalchuk GA, Verhoef HA, van der Heijden MGA (2010) Positive effects of organic farming on below-ground mutualists: Large-scale comparison of mycorrhizal fungal communities in agricultural soils. New Phytol 186:968-979. doi:10.1111/j.1469-8137.2010.03230.x

Waller JM, Bigger M, Hillocks RJ (2007) Coffee pests, diseases and their management. Cab International, Oxfordshire. doi:10.1079/ 9781845931292.0000 